Article

\title{
Land Change in the Greater Antilles between 2001 and 2010
}

\author{
Nora L. Álvarez-Berríos ${ }^{1, *}$, Daniel J. Redo ${ }^{2}$, T. Mitchell Aide ${ }^{2}$, Matthew L. Clark ${ }^{3}$ \\ and Ricardo Grau ${ }^{4}$
}

1 Department of Environmental Sciences, University of Puerto Rico, Río Piedras, P.O. Box 70377, San Juan, PR 00936, USA

2 Department of Biology, University of Puerto Rico, Río Piedras, P.O. Box 23360, San Juan, PR 00931, USA; E-Mails: daniel.j.redo@gmail.com (D.J.R.); tmaide@yahoo.com (T.M.A.)

3 Center for Interdisciplinary Geospatial Analysis, Department of Geography and Global Studies, Sonoma State University, Rohnert Park, CA 94928, USA; E-Mail: mateolclark@gmail.com

4 CONICET, Instituto de Ecología Regional, Universidad Nacional de Tucumán,

Casilla de Correo 34 (4107), Yerba Buena, Tucumán, Argentina; E-Mail: chilograu@gmail.com

* Author to whom correspondence should be addressed; E-Mail: alvarez.nora@gmail.com;

Tel.: +1-787-764-0000 (ext. 4865); Fax: +1-787-772-1459.

Received: 6 January 2013; in revised form: 28 February 2013 / Accepted: 18 March 2013 /

Published: 26 March 2013

\begin{abstract}
Land change in the Greater Antilles differs markedly among countries because of varying socioeconomic histories and global influences. We assessed land change between 2001 and 2010 in municipalities (second administrative units) of Cuba, Dominican Republic, Haiti, Jamaica, and Puerto Rico. Our analysis used annual land-use/land-cover maps derived from MODIS satellite imagery to model linear change in woody vegetation, mixed-woody/plantations and agriculture/herbaceous vegetation. Using this approach, we focused on municipalities with significant change $(p \leq 0.05)$. Between 2001 and 2010, the Greater Antilles gained $801 \mathrm{~km}^{2}$ of woody vegetation. This increase was mainly due to the return of woody vegetation in Cuba, and smaller increases in Puerto Rico and the Dominican Republic. Despite relatively similar environments, the factors associated with these changes varied greatly between countries. In Puerto Rico, Dominican Republic, and Jamaica, agriculture declined while mixed-woody vegetation increased, mostly in montane regions. In contrast, Cuba experienced an extensive decline in sugarcane plantations, which resulted in the spread of an invasive woody shrub species and the increase in woody vegetation in areas of high agricultural value. In Haiti, the growing population, fuelwood consumption, and increase in agriculture contributed to woody vegetation loss; however,
\end{abstract}


woody vegetation loss was accompanied with a significant increase in the mixed woody and plantations class. Most regional analyses often treated the Greater Antilles as a homogeneous unit; our results suggest that historical and socio-economic differences among countries are crucial for understanding the variation in present day land change dynamics.

Keywords: random forests; MODIS; Cuba; Dominican Republic; Haiti; Jamaica; Puerto Rico; SIDS; sugarcane

\section{Introduction}

Land change is considered a major contributor of global environmental change. Estimates indicate that human land change has impacted $\sim 40 \%$ of the earth's ice-free terrestrial surface, mostly due to the conversion of natural ecosystems (e.g., forests, savannas, and grasslands) to croplands and pasture [1]. The impacts of land changes over ecosystems are greater across the tropics where land conversion for agriculture mostly occurs over intact forested lands [2]. Central to land-change research is to identify the different land change trajectories (i.e., deforestation and reforestation) and to understand how to balance land conversion to meet human needs while preserving natural ecosystems.

Land change is the result of the interaction of multiple social, economic, and environmental factors occurring at multiple and hierarchical spatial scales (e.g., local, regional, global) [3]. Human population change, rural to urban migration, consumption patterns, presence and effectiveness of social institutions, and land-use policies are all examples of local factors that can influence patterns of land change [4,5]. Examples of regional or global factors include the increasing global demand for agricultural products, shifts in regional economies, indirect effects of tourism, and globalization of markets [5]. In addition, climate change and variability (e.g., droughts, tropical storms) are often important factors influencing land change [6].

From a regional perspective, certain geographic areas are more vulnerable to the combined effects of global climate, socio-political, and economic factors affecting land change [3,7]. This is evident in small island developing states (SIDS), which share challenges of susceptibility to natural disasters, limited natural and economic resources, comparatively larger influence of international forces (e.g., trade, food dependence, export demands, migration flows, remittances), high population densities, vulnerability to the invasion of exotic species, and fragile environments [8]. For example, four of the ten countries with the highest deforestation rates between 1990 and 2000 (3\% or more per year) were island states (Haiti, St. Lucia, Federated States of Micronesia, and Comoros); these deforestation rates were associated with agricultural expansion (for local and international markets), and infrastructure development (e.g., roads, ports, housing and tourism) $[9,10]$. Conversely, reforestation in islands can result from changes in the international demand for agricultural products and other commodities [9]. For instance, a decline in deforestation rates in the Caribbean Lesser Antilles between 1990 and 2000 has been related to the decline in the banana industry when the islands lost their preferential access to the European banana market [10]. In addition, extreme climate events can also have enormous impacts on land change, and can amplify the pressures arising from high demands 
on an island's scarce resources. For example, in Samoa, most native forest has been lost or degraded for timber production from plantations; however, plantations are much more vulnerable to cyclones and in the 1990s, over $90 \%$ of the island's plantations were lost in tropical storms Ofa and Val [9]. These examples illustrate the importance of analyzing land change in the context of natural and human factors at local and global scales.

Although the Greater Antilles are one of the most globalized regions of the world [11], one of the most vulnerable to climate fluctuations [12], and an important biodiversity hotspot [13], land change analyses of this region have been limited to individual countries or sub-countries areas and conducted in different time periods, making it difficult to compare among countries [14]. Because of its strategic geographical position, the region has been strongly shaped by the historic, cultural, and economic influence of global political powers (e.g., Spain, France, UK, USSR, USA), as well as by the cyclical exposure to climatic events (e.g., droughts and tropical storms). Since the early European colonization during the 16th century, the region has long been cultivated to supply the international demand for food commodities, especially bananas and sugar [11]. Most land change studies in the region have focused on Puerto Rico [15-17], while neglecting the other Greater Antilles countries. For example, in the Dominican Republic and Jamaica, studies have been limited to processes of deforestation and forest recovery at the sub-national level $[18,19]$. In Haiti, a few land change studies have documented deforestation at the watershed and country scale [20,21]. Remarkably, in Cuba, the largest island, land change information mainly relies on global-scale mapping efforts of poor local scale quality (e.g., GLF 2000) and government statistics.

A simultaneous assessment of current patterns and drivers of land change in the Greater Antilles provides the opportunity to understand how globalization, climate variability, and socio-economic conditions are affecting land change in this region; and more generally, how different local socioeconomic contexts interact with global factors to determine land use trends in tropical islands. This study aims to fill this gap by assessing the trends of land change between 2001 and 2010 in the five countries of the Greater Antilles (i.e., Cuba, Dominican Republic, Haiti, Jamaica, and Puerto Rico). We used MODIS MOD13Q1 imagery and a decision tree approach for image classification, and relied upon analyses of peer-reviewed articles to examine local, regional, and international factors associated with past and present patterns of land change. The major objectives were to: (i) analyse patterns of land change in the Greater Antilles during the last decade (2001-2010); (ii) identify hotspots of land change; and (iii) discuss the historical and contemporary factors associated with these changes.

\section{Study Site}

\section{Physical Environment and Land-Use History}

The study area includes the five countries of the Greater Antilles: Cuba, Dominican Republic, Haiti, Jamaica, and Puerto Rico, which cover $\sim 207,435 \mathrm{~km}^{2}$. In 2010 , the total regional population was estimated at 37.7 million (Table 1) and the average population density was 182 people $/ \mathrm{km}^{2}$ [22]. Vegetation type is highly variable between and within islands. Moist forests predominate in Puerto Rico, Hispaniola (Haiti and Dominican Republic), and Jamaica. Dry forests are largely confined to Cuba, though smaller pockets can be found in southern Puerto Rico, Jamaica, and Hispaniola. Conifer 
forests are found only in western Cuba, Dominican Republic, and southern Haiti [23]. Cuba is the only island with substantial wetlands and desert/xeric shrub biomes. Mangroves fringe all of the islands.

Table 1. Description of the principal demographic and socio-economic features of the Greater Antilles countries. Data are from [24].

\begin{tabular}{|c|c|c|c|c|c|c|c|c|c|}
\hline & & Pop & & Urban Pop & & & & & \\
\hline & $\begin{array}{c}\text { Pop in } \\
2010 \\
\left(\times 10^{3}\right)\end{array}$ & $\begin{array}{c}\text { Density in } \\
2010 \\
(\text { People } \\
\left.\text { per } \mathbf{k m}^{2}\right)\end{array}$ & $\begin{array}{c}\text { \% Urban } \\
\text { Pop in } \\
2010\end{array}$ & $\begin{array}{c}\text { Growth } \\
\text { Rate } \\
(2010- \\
2015) \\
\end{array}$ & $\begin{array}{c}\text { Rural Pop } \\
\text { Growth Rate } \\
\text { (2010-2015) }\end{array}$ & $\begin{array}{c}\text { GDP per } \\
\text { Capita } \\
(2010)^{a}\end{array}$ & $\begin{array}{l}\text { \% GDP in } \\
\text { Agriculture } \\
\quad(2010)\end{array}$ & $\begin{array}{l}\text { HDI }^{b} \\
(2011)\end{array}$ & $\begin{array}{c}{ }^{\#} \text { of } \\
\text { Municipalities }\end{array}$ \\
\hline Cuba & 11,258 & 106 & $75.2 \%$ & $-0.08 \%$ & $0.04 \%$ & 5,397 & 4.99 & 0.776 & 169 \\
\hline $\begin{array}{l}\text { Dominican } \\
\text { Republic }\end{array}$ & 9,927 & 205 & $69.1 \%$ & $2.03 \%$ & $-0.70 \%$ & 5,195 & 6.22 & 0.689 & $31^{\mathrm{c}}$ \\
\hline Haiti & 9,993 & 363 & $52.0 \%$ & $3.68 \%$ & $-1.68 \%$ & 664 & NA & 0.454 & 567 \\
\hline Jamaica & 2,741 & 250 & $52.0 \%$ & $0.51 \%$ & $0.18 \%$ & 5,163 & 6.29 & 0.727 & 14 \\
\hline Puerto Rico & 3,749 & 420 & $98.8 \%$ & $0.06 \%$ & $-9.60 \%$ & 25,863 & 0.57 & 0.867 & 78 \\
\hline
\end{tabular}

${ }^{a}$ Data for Cuba is for 2008; ${ }^{b}$ HDI for Puerto Rico is for $2004 ;{ }^{c}$ In the case of Dominican Republic, the analyses were done at the first administrative division (Provinces).

Historically, agriculture in the Greater Antilles has been dominated by sugarcane, coffee plantations, and pastures for cattle production. Other land uses include the farming of tobacco, bananas, cocoa, yams, and citrus, as well as mining operations (e.g., nickel and cobalt in Cuba, gold and nickel in the Dominican Republic, and bauxite in Jamaica). Today, tourism, service sectors, manufacturing, and foreign aid (Haiti) are fuelling much of the region's economic growth.

\section{Political and Socio-Economic Background}

The socio-political characteristics of the Greater Antilles vary greatly among countries given their histories of colonization and associations with foreign powers. The Greater Antilles were disputed territories of several European countries and the United States during a series of occupations and political interventions going back 500 years. Cuba, Puerto Rico, and the Dominican Republic were predominantly occupied by Spain, while Jamaica and Haiti by the United Kingdom and France, respectively. These countries obtained total independence during the 19th and 20th century, except for Puerto Rico that remains an unincorporated territory of the United States since 1898 (when transferred from Spain under the terms of the Treaty of Paris after the Spanish American War). Today, Puerto Rico is a Commonwealth of the United States. Cuba has a socialist political system lead by the Communist Party since the Cuban Revolution in 1959, formerly aided by an economic alliance with USSR until its dissolution in 1991. Predominantly under the influence of Britain for $\sim 300$ years, Jamaica continues to have ties with United Kingdom as a Commonwealth nation, but trade, financial, and cultural relations with the United States are now predominant. The Dominican Republic, in turn is a democratic republic established after years of political turmoil during the military regimes that controlled the country between the 1930s and 1960s. In Haiti, political violence and government instability has occurred throughout its history, prompting the intervention of international organizations for political resolution and economic aid principally by US, Canada, and the European Union. The differences in political and socio-economic histories in these countries are reflected in their wide range of contemporary social 
and economic conditions (e.g., large difference in GDP per capita) (Table 1). Haiti is the poorest nation of the Greatest Antilles and the western hemisphere, according to the HDI poverty measures (Table 1); while Puerto Rico has one of the largest per capita GDP in Latin America.

\section{Experimental Section}

\section{Mapping Land Change}

The land-use/land-cover classification methodology is described in detail in Clark et al. [25], and is summarized below. We used the MODIS MOD13Q1 Vegetation Index image product (16-day L3 Global $250 \mathrm{~m}$ ) for the entire study area to map land use and land cover. The product is a 16-day composite of the highest quality pixels from daily images and includes: the blue (459-479 nm), red (620-670 nm), near infrared (NIR: 841-876 nm), and mid-infrared (MIR: 2105-2155 nm) bands, the NDVI and EVI indices, and the pixel reliability band. A total of 23 scenes are provided for each year between 2001 and 2010 [26]. We classified the imagery using a Random Forests classifier into eight classes of vegetation/areas: (1) woody; (2) mixed-woody; (3) herbaceous; (4) agriculture; (5) plantations; (6) bare; (7) built-up; and (8) water [25]. Random Forests classifiers have proved useful in detecting land cover and land use elsewhere [25,27]. They are decision-tree algorithms, which employ bootstrap samples with replacement to grow a large set of classification trees [28]. Pixels are assigned to the classes that receive the most votes from the user-specified number of classification trees.

Training and testing (or reference) data were collected with human interpretation of high-resolution imagery in Google Earth using interpretation criteria and a Web-based tool [29]. Google Earth provides high-resolution imagery from data sources such as DigitalGlobe, GeoEye-1, IKONOS, and EarthSat with spatial resolutions often as fine as $<1$ to $4 \mathrm{~m}$. A total of 1,488 samples were placed only in areas with high resolution QuickBird imagery, well within patch types for the corresponding land cover classes, and more than 1,000 m apart. No field data were acquired for classifier training and accuracy assessment due to the large size of the study area, cost associated with covering such an extensive area, and access to high-resolution imagery in Google Earth.

Predictor variables were MODIS-derived statistics extracted for the year corresponding to the QuickBird image year (range 2001 to 2010) for each reference sample. For each pixel, we calculated the statistics mean, standard deviation, minimum, maximum and range for EVI, NDVI, red, NIR and MIR reflectance values from calendar years 2001 to 2010. These statistics were calculated for three 4-month, two 6-month, and one 12-month periods in a calendar year. The pixel reliability layer was used to remove all unreliable samples (e.g., no data or cloud-covered samples) prior to calculating statistics. To create the classification, an initial Random Forests classifier [30] was generated with 1,999 trees within the R statistical package [31]. The outlier function in the Random Forests module was used to eliminate samples with an outlier metric greater than 10, and a final Random Forests classifier was generated from the remaining samples using all predictor variables (4-, 6-, and 12-month statistics for red, NIR, MIR, and EVI). A secondary Random Forests classifier was generated using just 12-month statistics. We used a custom program to apply the final Random Forests classifier object to every pixel in the Greater Antilles for each year (from 2001 to 2010) (see Clark et al. [25]). A map 
classification accuracy assessment was based on the information obtained from reference data that were not used in training an individual tree in the Random Forests classifier [28]. In constructing an individual tree, Random Forest samples are $\sim 2 / 3$ of the reference data with replacement, while $\sim 1 / 3$ of the reference data is withheld for accuracy assessment (also known as 'out of samples' or OOB samples). The OOB samples are then sent down trees for which they were not used, and the difference between the predicted and actual class is used to calculate an error matrix and unbiased estimate of accuracy [28]. To increase accuracy, we further performed a post-classification merging of the original eight classes of vegetation/areas into five classes: (1) woody; (2) agriculture/herbaceous vegetation; (3) mixed-woody/plantations; (4) bare/built-up areas; and (5) water (Table 2). Woody vegetation was trees and shrubs with $>80 \%$ cover. Agriculture/herbaceous vegetation was annual crops, grasslands, and pastures with $>80 \%$ cover. Mixed-woody/plantations was woody vegetation with a 20 to $80 \%$ cover, including agriculture/herbaceous vegetation or bare soil as background, as well as all forms of plantations and perennial agriculture. Bare/built-up areas were exposed soil and rock, and areas with $<20 \%$ vegetation cover and $>80 \%$ man-made or urban structures. Finally, water included all types of freshwater bodies and watercourses.

Table 2. Overall producer and user accuracies for the five-class land-cover maps.

\begin{tabular}{|c|c|c|c|c|c|c|c|}
\hline Reference Samples & $\begin{array}{l}\text { Agriculture/ } \\
\text { Herbaceous }\end{array}$ & $\begin{array}{l}\text { Bare Ground/ } \\
\text { Built-up }\end{array}$ & $\begin{array}{c}\text { Mixed Woody/ } \\
\text { Plantations }\end{array}$ & $\begin{array}{l}\text { Water } \\
\text { Bodies }\end{array}$ & $\begin{array}{c}\text { Woody } \\
\text { Vegetation }\end{array}$ & Total & User \\
\hline Agriculture/Herbaceous & 339 & 4 & 87 & 0 & 10 & 440 & $77.0 \%$ \\
\hline Bare ground/Built-up & 11 & 204 & 5 & 0 & 1 & 221 & $92.3 \%$ \\
\hline Mixed woody/Plantations & 74 & 0 & 256 & 0 & 58 & 388 & $66.0 \%$ \\
\hline Water bodies & 0 & 3 & 1 & 111 & 0 & 115 & $96.5 \%$ \\
\hline Woody vegetation & 12 & 0 & 93 & 0 & 219 & 324 & $67.6 \%$ \\
\hline Total & 436 & 211 & 442 & 111 & 288 & 1,488 & \\
\hline Producer & $77.8 \%$ & $96.7 \%$ & $57.9 \%$ & $100.0 \%$ & $76.0 \%$ & & $75.9 \%$ \\
\hline
\end{tabular}

The average overall accuracy of this five-class map was $76 \%$. Together, the mixed-woody/plantations and the agriculture/herbaceous vegetation classes accounted for most of the inaccuracy since they could not be well differentiated from one another. Bare/built-up areas were grouped together as they yielded low accuracy values when mapped separately. This is because bare/built-up areas have highly reflective surfaces and spectral similarities that are difficult to differentiate with MODIS 13 [25]. Hence, we did not consider the urban (i.e., built-up) land cover change in this analysis.

To present trends in land change for the Caribbean Antilles over the 2001-2010 period, we focused on three land classes from our five-class scheme: woody, mixed-woody/plantations, and agriculture/herbaceous vegetation. Analysis of land changes were done for a total of 828 municipalities (Cuba with 169 municipalities; Haiti with 567; Jamaica with 14; Puerto Rico with 78), and 31 provinces (Dominican Republic; here referred to as municipalities). Municipality polygons ( $n=859)$ were overlaid on our mosaicked land cover maps, 2001 to 2010. For each municipality, we estimated the area $\left(\mathrm{km}^{2}\right)$ of change for woody, mixed-woody/plantations, and agriculture/herbaceous vegetation for each year between 2001 and 2010. To minimize errors associated with interannual fluctuations, we conducted a linear regression of class area (dependent variable) against time (independent variable, each of the 10 years between 2001 and 2010) (859 municipalities $\times 3$ classes $=2,577$ models) (see Clark et al. [25]). If more than $1 \%$ of the total municipality area had pixels mapped as No Data for 
a given year, then the land cover data for that year were removed from the regression. Regression models were only fit for municipalities that had $\geq 3 \mathrm{yr}$ with valid areas of land cover data. Absolute areas of woody vegetation, mixed-woody/plantations, and agriculture/herbaceous vegetation were reported for 2001 and 2010 using estimates from the linear regression model developed for each municipality. Only the municipalities that experienced significant change $(p \leq 0.05)$ in these classes were included in the analyses presented in the present study. To determine the strength of this linear relationship we used Pearson's correlation coefficient (R), where positive values of $R$ represent an increase in a land cover and negative values of $\mathrm{R}$ represent a decrease. We used this approach to standardize land change through time due to outliers or missing data in any given year, and the use of $\mathrm{R}$ for trends allows us to compare municipalities, which can vary in size from $4 \mathrm{~km}^{2}$ to $3,795 \mathrm{~km}^{2}$. By using a regression model to estimate change in vegetation/areas from 2001 to 2010 (as opposed to using raw area values from maps for these years), we were able to benefit from several distinct advantages. First, a regression model reduces the effect of erroneous outliers in either 2001 or 2010. For example, if a municipality experienced steady woody vegetation loss from 2001 to 2009 and then experienced an unusual climate event (e.g., drought) that could temporarily change woody vegetation cover in 2010 , the regression model would minimize the effect of the outlying data point. Second, we could take into account every year within our period of interest (2001 to 2010) and eliminate years with relatively poor land-cover mapping due to cloud cover and other artifacts, thus minimizing errors introduced by any given year. Finally, our regression approach allowed us to focus our analysis on those municipalities within a country that had statistically-significant land-cover change. In analysing our results, we compare our land change estimates with data reported by FAO. We recognize that the use of FAO data for land cover studies has limitations (e.g., inconsistencies in the definitions of land cover classes (e.g., forests) over the years) [32]; however, given the paucity land cover data for the Antilles countries, FAO data constitute one of the few available source of country-scale data with statistics up to 2010.

\section{Results}

Between 2001 and 2010, 51 (5.9\%) of the municipalities in the Greater Antilles significantly gained woody vegetation, while only 20 (2.3\%) significantly lost woody vegetation (Figure 1(a); Table S1; $p \leq 0.05)$. Although the majority of municipalities $(\mathrm{n}=788,91.8 \%)$ did not show a significant change in woody vegetation, the net decadal change in woody vegetation cover for municipalities with significant change (Table 3), as well as for all municipalities (i.e., non-significant change in addition to significant change) (Table 4) was positive. Overall, the area in woody vegetation increased by $801 \mathrm{~km}^{2}$ (Table 3). Nearly all (99.8\%) of this increase occurred in Cuba $\left(+799 \mathrm{~km}^{2}\right)$, but there were also small increases in woody vegetation in Puerto Rico $\left(+19 \mathrm{~km}^{2}\right)$ and Dominican Republic $\left(+4 \mathrm{~km}^{2}\right)$. These increases were only partially offset by losses of woody vegetation in Haiti $\left(-21 \mathrm{~km}^{2}\right)$. 
Figure 1. Gain (blue dots) and loss (orange dots) in: (a) woody vegetation; (b) agriculture/herbaceous; (c) mixed-woody/plantations, from 2001 to 2010 in $\mathrm{km}^{2}$. Only municipalities with a significant $(p \leq 0.05)$ 10-year trend and more than $5 \mathrm{~km}^{2}$ of change are highlighted.
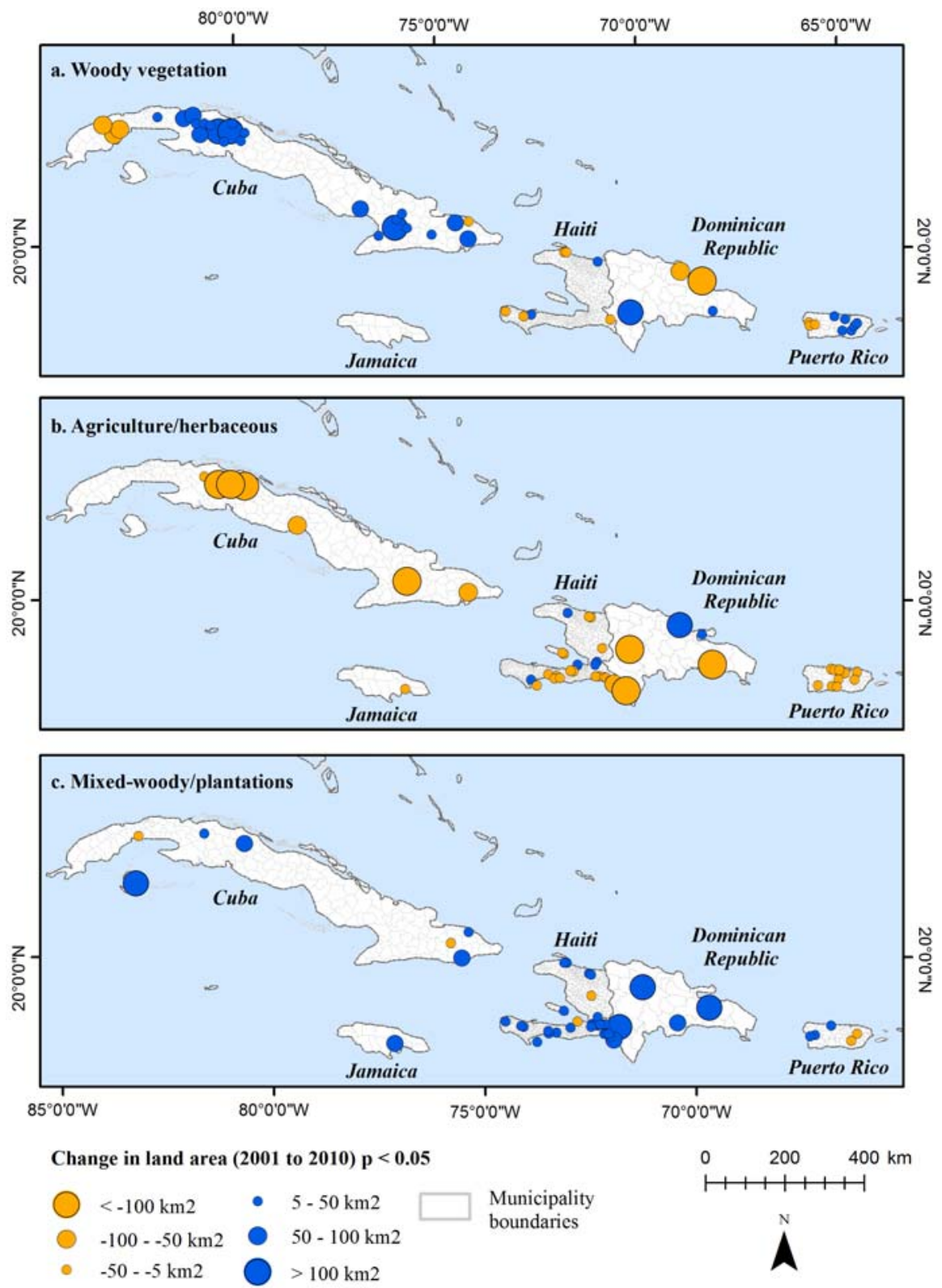

Table 3. Net changes in land-use and land-cover from 2001 to 2010 , (in $\mathrm{km}^{2}$, and $\%$ of land in each country) only for municipalities that underwent significant change $(p \leq 0.05)$.

\begin{tabular}{|c|c|c|c|c|c|c|}
\hline & \multicolumn{2}{|c|}{ Woody Vegetation } & \multicolumn{2}{|c|}{ Agriculture/Herbaceous } & \multicolumn{2}{|c|}{ Mixed-Woody/Plantations } \\
\hline & $\left(\mathrm{km}^{2}\right)$ & $\%$ & $\left(\mathrm{~km}^{2}\right)$ & $\%$ & $\left(\mathrm{~km}^{2}\right)$ & $\%$ \\
\hline Cuba & +799 & 0.73 & -753 & 0.69 & +327 & 0.30 \\
\hline Dominican Republic & +4 & 0.00 & -301 & 0.62 & +707 & 1.46 \\
\hline Haiti & -21 & 0.08 & -317 & 1.14 & +368 & 1.33 \\
\hline Jamaica & 0 & 0.00 & -8 & 0.07 & +60 & 0.55 \\
\hline Puerto Rico & +19 & 0.21 & -119 & 1.31 & +26 & 0.29 \\
\hline Total & +801 & & $-1,498$ & & $+1,488$ & \\
\hline
\end{tabular}


Table 4. Percentage of the countries (\% land) in the different land classes in 2001 and 2010. These percentages include all municipalities within a country (i.e., non-significant change in addition to significant change).

\begin{tabular}{lcccccc}
\hline & \multicolumn{2}{c}{ \% Woody Vegetation } & \multicolumn{2}{c}{ \% Agriculture/Herbaceous } & \multicolumn{2}{c}{ \% Mixed-Woody/Plantations } \\
\cline { 2 - 7 } & $\mathbf{2 0 0 1}$ & $\mathbf{2 0 1 0}$ & $\mathbf{2 0 0 1}$ & $\mathbf{2 0 1 0}$ & $\mathbf{2 0 0 1}$ & $\mathbf{2 0 1 0}$ \\
\hline Cuba & 22 & 24 & 49 & 43 & 25 & 28 \\
Dominican & 31 & 31 & 30 & 27 & 35 & 39 \\
Republic & & & & & 28 & 32 \\
Haiti & 7 & 57 & 53 & 37 & 38 \\
Jamaica & 46 & 43 & 15 & 17 & 38 & 40 \\
Puerto Rico & 30 & 31 & 23 & 19 & 14 & 15 \\
\hline Total & 12 & 13 & 26 & 23 & & \\
\hline
\end{tabular}

During this period, $50(5.8 \%)$ municipalities in the Greater Antilles significantly lost agriculture/herbaceous vegetation, while only $13(1.5 \%)$ significantly gained agriculture/ herbaceous vegetation (Figure 1(b); Table S1). Concurrently, 52 (6.1\%) municipalities gained mixed-woody/plantations, while 16 (1.9\%) experienced a decrease in this class (Figure 1(c)). Overall, the Greater Antilles lost approximately $1,498 \mathrm{~km}^{2}$ from the agriculture/herbaceous vegetation class (Table 3). Most of this loss occurred in Cuba $\left(-753 \mathrm{~km}^{2}\right)$, followed by Haiti $\left(-317 \mathrm{~km}^{2}\right)$, the Dominican Republic $\left(-301 \mathrm{~km}^{2}\right)$, Puerto Rico $\left(-119 \mathrm{~km}^{2}\right)$ and Jamaica $\left(-8 \mathrm{~km}^{2}\right)$. In contrast, all countries experienced increases in areas classified as mixed-woody/plantations (Figure 1(c); Table 3). Most of this gain occurred in the Dominican Republic $\left(+707 \mathrm{~km}^{2}\right)$, followed by Haiti $\left(+368 \mathrm{~km}^{2}\right)$, Cuba $\left(+327 \mathrm{~km}^{2}\right)$, Jamaica $\left(+60 \mathrm{~km}^{2}\right)$, and Puerto Rico $\left(+26 \mathrm{~km}^{2}\right)$.

\section{Patterns of Land Change by Country}

Cuba

Between 2001 and 2010, 29 municipalities experienced significant woody vegetation change in Cuba: 22 had an increase and 7 had a decrease in this class. Woody vegetation gain was largely concentrated in the west-central and southeast municipalities (e.g., west-central: Los Arabos, Santo Domingo, Jagüey Grande, Cárdenas, and Limonar; southeast: Bayamo, Sagua de Tánamo, Manuel Tames, and Colombia), whereas woody vegetation loss was concentrated in municipalities in western Cuba (e.g., La Palma, San Cristóbal, Los Palacios) (Figure 1(a); Table S1).

Cuba also experienced significant changes in the agriculture/herbaceous vegetation and mixed-woody/ plantations class (Figure 1(b,c)). Seven municipalities lost agriculture/herbaceous vegetation, mainly in the same municipalities that gained woody vegetation in the west (e.g., Los Arabos, Santo Domingo, and Cifuentes) and southeast region of the island (e.g., Manuel Tames and Jiguaní). No municipality had a significant increase in agriculture/herbaceous class. Between 2001 and 2010, five municipalities gained mixed-woody/plantations, while three lost mixed-woody/plantations. Changes in mixedwoody/plantations vegetation concentrated in the southeast and west regions of the country (e.g., Isla de la Juventud, Cifuentes, and Caimanera). 


\section{Puerto Rico}

From 2001 to 2010, nine municipalities in Puerto Rico experienced an increase in woody vegetation, while three lost woody vegetation. Municipalities that experienced the greatest increase in woody vegetation are concentrated in the central and southern mountains (Gurabo, Caguas, Cayey, Coamo), and along the northern coast (Toa Alta and Manatí). Woody vegetation loss was confined to three adjacent municipalities in the west (Mayagüez, Añasco, and Las Marías) (Figure 1(a); Table S1).

Puerto Rico also experienced a significant trend in the mixed-woody/plantations class: three municipalities had an increase, while four municipalities had a decrease in this class. The municipalities that increased in mixed-woody/plantations were located in the west overlapping with areas of significant woody vegetation loss (Mayagüez and Las Marías), and in the northern coast (Barceloneta) (Figure 1(c)). Losses for agriculture/herbaceous vegetation were the most widespread and encompassed the greatest number of municipalities: 13 lost agriculture/herbaceous vegetation, while no municipality gained (Figure 1(b)). Agriculture/herbaceous vegetation losses were generally confined to the northern Atlantic coast and the southern Caribbean coast. The highest losses of agriculture/herbaceous vegetation (Manatí, Toa Alta and Juana Díaz) were also the areas that gained the highest area in woody vegetation (Table S1).

\section{Dominican Republic}

From 2001 and 2010, four municipalities experienced a significant trend of woody vegetation change: two gained and two lost woody vegetation. Loss of woody vegetation was confined to the southwest (Bahoruco) and southeast (San Pedro de Macorís). The two municipalities with woody vegetation loss were adjacent and located on the north-eastern coast (e.g., Samaná and María Trinidad Sánchez) (Figure 1(a); Table S1).

In the agriculture/herbaceous class, there were six municipalities that experienced significant changes: two gained agriculture/herbaceous, while four lost agriculture/herbaceous (Figure 1(b)). Losses of agriculture/herbaceous vegetation were concentrated in the southern and western half of the country (e.g., San Pedro de Macorís, San Juan, and Pedernales). The Dominican Republic had the municipality with the highest gain of agriculture/herbaceous vegetation (María Trinidad Sánchez; 110 $\mathrm{km}^{2}$ ) in all of the Greater Antilles (mostly rice cultivation) [33]. This same municipality also had the highest loss for woody vegetation.

Four municipalities experienced a positive trend in the mixed-woody/plantations vegetation, while no municipality experienced a negative trend in this class. Gains in areas of mixed-woody/plantations were more dispersed compared to other classes (Figure 1(c)). The largest gains occurred in the north-central (Santiago), the southwest (Independencia,) and the eastern regions of the country (Hato Mayor).

Haiti

From 2001 to 2010, 26 municipalities in Haiti experienced a significant trend of woody vegetation change: 18 experienced increases and eight experienced decreases in this class. In contrast with the other countries, the Haitian municipalities that had significant gain in woody vegetation were as widely dispersed as municipalities that had significant losses in woody vegetation (Figure 1(a)). The greatest 
areas of woody vegetation gain were detected in the northeast (Fonds Blanc) and the southwest (Fond Tortue), while the greatest areas of woody vegetation loss were notably in the westernmost area of the island (municipalities of Dejean and Duchity), the northeast (Rivière de Barre, Borneau, and Mayance), and along the border with the Dominican Republic (municipality of Fonds-Ferrettes) to the southeast (Figure 1(a); Table S1).

During this period, 48 municipalities had a significant trend in mixed-woody/plantations: 39 experienced an increase, while nine experienced a decrease. The largest gains in areas of mixed-woody/plantations concentrated in the southeast (e.g., Boucan Guillaume, Pichon, and Mapou) (Figure 1(c)). Losses of agriculture/herbaceous vegetation were much more dispersed, but largely took place along the Plaine de l'Artibonite (the most important agricultural valley in the country), or in the same areas of increasing mixed-woody/plantations (with Boucan Guillaume showing $>50 \mathrm{~km}^{2}$ losses) (Figure 1(b,c)). In total there were 36 municipalities that experienced a significant change in the agriculture/herbaceous class: 11 gained and 25 lost area.

Jamaica

Between 2001 and 2010, no municipality in Jamaica experienced a significant trend in the woody class (Table 3). Only one municipality had a significant increase in mixed-woody/plantations (St. Catherine), and one municipality had a significant decrease in agriculture/herbaceous vegetation (Kingston). The significant changes in land cover occurred in the southern part of Jamaica (Figure 1(b,c)).

\section{Discussion}

Our study assessed trends in land change in the Greater Antilles based on the municipalities that underwent significant change $(\mathrm{p} \leq 0.05)$ between 2001 and 2010. There were significant increases in the mixed-woody/plantations class, and decreases in the agricultural/herbaceous vegetation class throughout the region. Reforestation (gain of woody vegetation (i.e., trees and shrubs) through natural regeneration, encroachment, or direct human intervention) is at an advanced stage in Cuba, Puerto Rico, and the Dominican Republic, as revealed by a significant increase in the woody vegetation class; however, deforestation (loss of woody vegetation through conversion, selective logging, and degradation) continued to be a significant trend of land-cover change in Haiti, whereas in Jamaica the area under woody vegetation remained stable. Overall, trends of land change in the countries of the Greater Antilles are closely associated with their historical and socio-economic context, strongly influenced by the relationship with global factors, and shaped by local environmental characteristics and planning decisions. Land change has also been largely influenced by the countries' vulnerability to the impacts of climatic events in the region (e.g., tropical storms, droughts).

\subsection{Land Change in Cuba}

The decline and recovery of Cuba's woody vegetation is closely linked to the rise and decline of the sugarcane industry; which in turn reflects the fall of the Soviet Union (Figure 2). Previous to the socialist revolution in 1959, Cuba was one of the world's largest producers of sugar largely under the control of US investors [34]. After 1959, the production of sugar cane increased further, to supply the 
demand of the Soviet Union, the principal and almost exclusive consumer of Cuba's sugar cane (Figure 2). Between 1970s and 1980s, sugarcane maintained high production levels and represented $\sim 75 \%$ of Cuba's exports and $\sim 20 \%$ of the island's economy $[35,36]$. Sugar production reached the highest levels in 1970 (during the '10 million ton sugar harvest strategy'), and between 1984 and 1992 (during the 'Green Revolution') (Figure 2), when previously forested lands were converted to sugarcane for export to the Soviet Union (and its Eastern European allies) [37]. But in December of 1991, the Soviet Union was officially dissolved, an event that initiated the 'Special Period' in Cuba and the end of the 'sugar-for-oil' exchange that had subsidized the sugarcane industry for decades (Figure 2). Without chemical inputs and fossil fuels subsides, machinery, and oil, and $85 \%$ of its market suddenly gone, food and fuel supplies began to dwindle [37,38]. Cuba attempted to diversify its agricultural production by growing fruits and vegetables on former sugarcane fields, but many of the former sugarcane fields reverted back to shrublands.

Figure 2. Change in sugarcane production (in tons) in Cuba from 1961 to 2009. Data used to construct this figure was obtained from FAOSTATS [33].

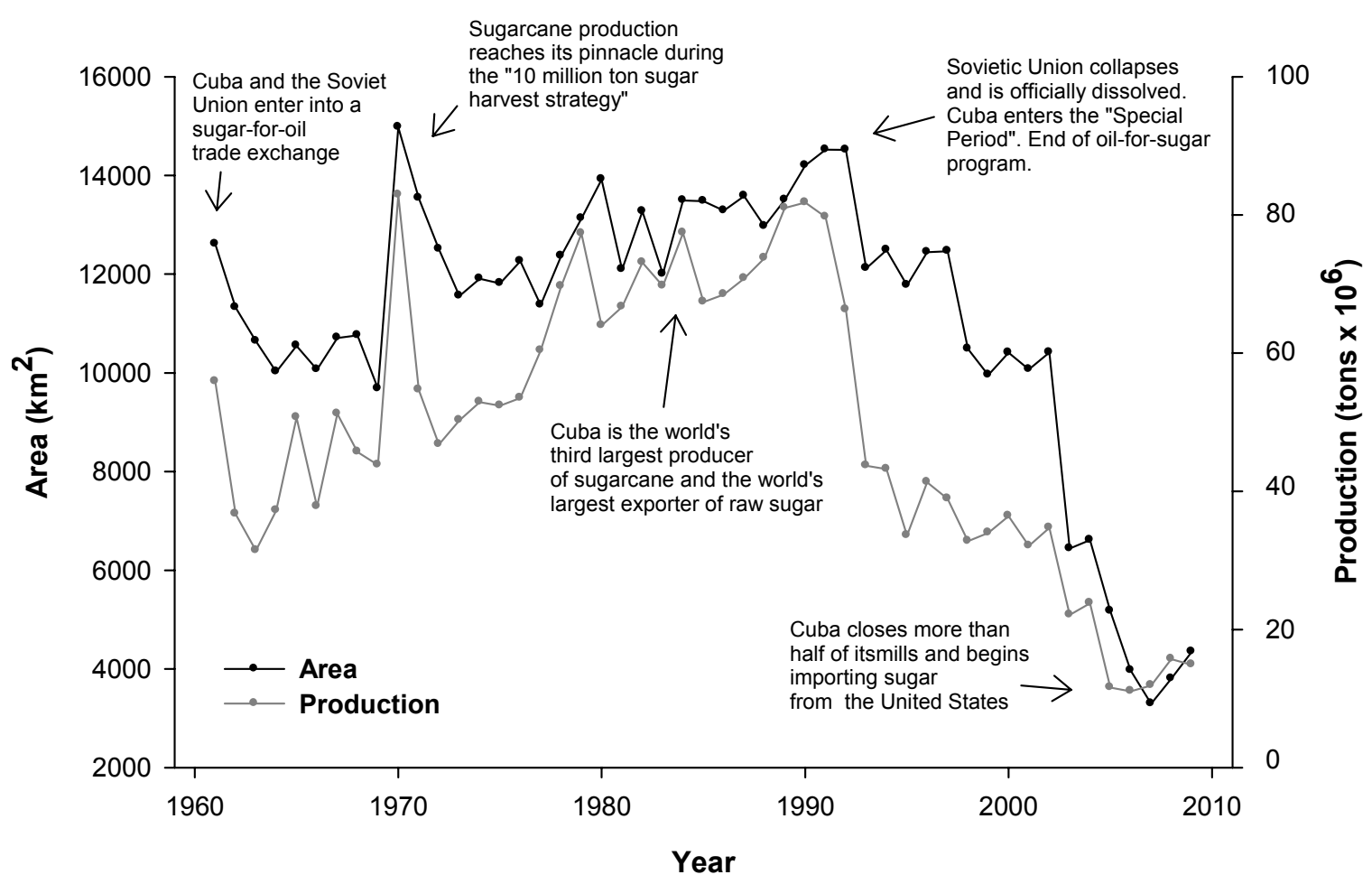

As a result of the decline in demand, underinvestment, and natural disasters (e.g., Hurricanes Michelle in 2001 and Charlie in 2004), sugar production in the 2000s continued to decline (Figure 2). From 1990 to 2000, area harvested declined by $27 \%$. From 2000 to 2008, it declined by another 58\%, and in 2002, more than half of Cuba's sugar mills were shut down. In total, Cuba has lost approximately $10,000 \mathrm{~km}^{2}$ or $70 \%$ of its sugarcane since the collapse of the Soviet Union. The area of other crops has also declined (Table 5), but there has been an increase in urban agriculture [37]. These losses in agricultural are reflected in our analyses where the agriculture/herbaceous class decreased by $\sim 753 \mathrm{~km}^{2}$, and the woody vegetation and mixed-woody/plantations classes increased by $\sim 799 \mathrm{~km}^{2}$, and $\sim 356 \mathrm{~km}^{2}$ respectively (Table 3). Municipalities that experienced significant decreases in agriculture in 
the central (Los Arabos, Santo Domingo and Cifuentes) and western region (Jiguani) also experienced significant increases in the woody vegetation class suggesting woody regrowth in abandoned agricultural lands.

Table 5. Net change in crop area harvested (2001 to 2008/09) in $\mathrm{km}^{2}$ and number of head of cattle (2001 to 2008). Data used to construct this figure was obtained from FAOSTATS [33].

\begin{tabular}{|c|c|c|c|c|c|c|c|c|}
\hline & All Cropland & Sugarcane & Coffee & Bananas & Cocoa Beans & Maize & Rice & Cattle \\
\hline Cuba & $-6,816$ & $-6,268$ & -312 & -64 & -4 & +10 & -28 & $-217,100$ \\
\hline Dominican Republic & -557 & -420 & -60 & -143 & +274 & -89 & -79 & 121,349 \\
\hline Haiti & +270 & +17 & +135 & +10 & +74 & +90 & +18 & 15,000 \\
\hline Jamaica & -26 & -52 & +5 & +20 & +2 & -2 & 0 & $-215,000$ \\
\hline Puerto Rico & -96 & -6 & -81 & -9 & 0 & 0 & 0 & $-16,350$ \\
\hline Total & $-7,224$ & $-6,729$ & -313 & -186 & +346 & +9 & -89 & $-312,101$ \\
\hline
\end{tabular}

Our analysis also detected decreases in woody vegetation in western and eastern Cuba between 2001 and 2010 (Figure 1(a)). The west region has frequent forest fires (e.g., 118 forest fires in 2009; mostly due to lighting), which can dramatically reduce woody vegetation cover (e.g., 3,829 ha lost in 2006; 1,014 in 2009) [39]. In addition, Palacios and San Cristóbal, two municipalities in western Cuba where we detected woody vegetation loss, are areas of active sugar cane cultivation. It is possible that some of the woody loss is due to sugar cane expansion in the last few years [40] (Figure 2). In eastern Cuba, significant losses in woody vegetation (Figure 1(a)) were associated with the expansion of the nickel and cobalt open-pit mine in the municipality of Moa [41].

The species of woody vegetation that have returned to the abandoned sugarcane fields are mostly non-native shrubs, predominantly consisting of El Marabú (Dichrostachys cinerea), an African fast-growing legume introduced to the Caribbean in the 1800s [42]. Ever since the 'Special Period' (1990s) (Figure 2), the Marabú has grown in abandoned pasture lands [37] and former sugarcane fields, and now covers an estimated $20,000 \mathrm{~km}^{2}$ [43]. This species is difficult to control and often requires the heavy use of herbicides; however, it is a source of fuelwood for local populations and by being a nitrogen fixing species may contribute to long term restoration of these lands [37].

Patterns of post-soviet land use change in Cuba, share characteristics with regions in Eastern Europe were millions of hectares of agricultural lands were abandoned after the collapse of the Soviet Union [44]. While woody recovery usually occurs on marginal lands (e.g., remote places, steep and poor soils) [45], case studies in post-socialist countries showed a distinctive patterns of reforestation after agricultural abandonment $[44,46]$. For example, in the regions of Ivano-Frankivska, Lvivska, and Zakarpatska in Western Ukraine, agricultural abandonment after the independence from the Soviet Union occurred regardless of land value, quality of soils for agriculture, or crop productivity [44,46]. Similarly, in Cuba, prime agricultural land was abandoned, permitting the recovery or encroachment of woody vegetation. In both cases, these lands were owned by the state, which is a very different land tenure system in comparison with other regions in Latin America, thus providing a different example of woody recovery.

The clustered spatial distribution of woody encroachment in diverse types of habitats with particular conservation value (e.g., dry forests and moist forests ecoregions) coupled with stable human population growth (11.1 million in 2000 and 11.3 million in 2010 [22]), provides a unique 
opportunity for conservation of reforesting sites in Cuba (e.g., design conservation corridors, expansion of protected areas). Conversely, in a scenario where the economy of Cuba opens to foreign investments, forested and shrublands could revert to intensive agriculture for export markets (e.g., sugarcane for the production of bioethanol).

\subsection{Land Change in Puerto Rico}

Puerto Rico is the most studied case of natural vegetation recovery in the Caribbean $[17,47,48]$, and possibly the best-documented example of woody recovery in Latin America [47]. Historically, the island's economy depended mainly on agriculture and cattle grazing, which resulted in extensive clearing of the island's woody cover [15] (Figure 3). Consequently, by the 1940s, remnant woody vegetation covered only 5\%-6\% of the island [49]. In 1948, the U.S. government initiated 'Operation Bootstrap', an attempt to industrialize the island by attracting private industries through tax exemptions, lack of import duties in US markets, and coupled with local relatively cheap labour [50]. The island has transitioned from an agriculture-based rural economy (e.g., sugarcane, coffee, and pineapple) to an industrial-based (e.g., light manufacturing, technology) and service-based urban economy [15]. As a result, agricultural lands in Puerto Rico decreased from 85\% in 1940 to $37 \%$ in 1980 [51]; by 1980, agriculture accounted for only 5\% of the GNP, whereas manufacturing accounted for $\sim 50 \%$ [52]. The abandonment of marginal agricultural lands [17], coupled by the decline in rural population caused by outmigration to urban areas [15] permitted the recovery of the woody cover especially in the mountainous interior [17]. Woody recovery continued in the following decades, and by the early 2000 s, woody cover in Puerto Rico extended over $50 \%-57 \%$ of the island [53].

Figure 3. Change in woody and agricultural area (in $\mathrm{km}^{2}$ ) in Puerto Rico from $\sim 1600$ to 2010. Data used to construct this figure was obtained from $[33,54]$.

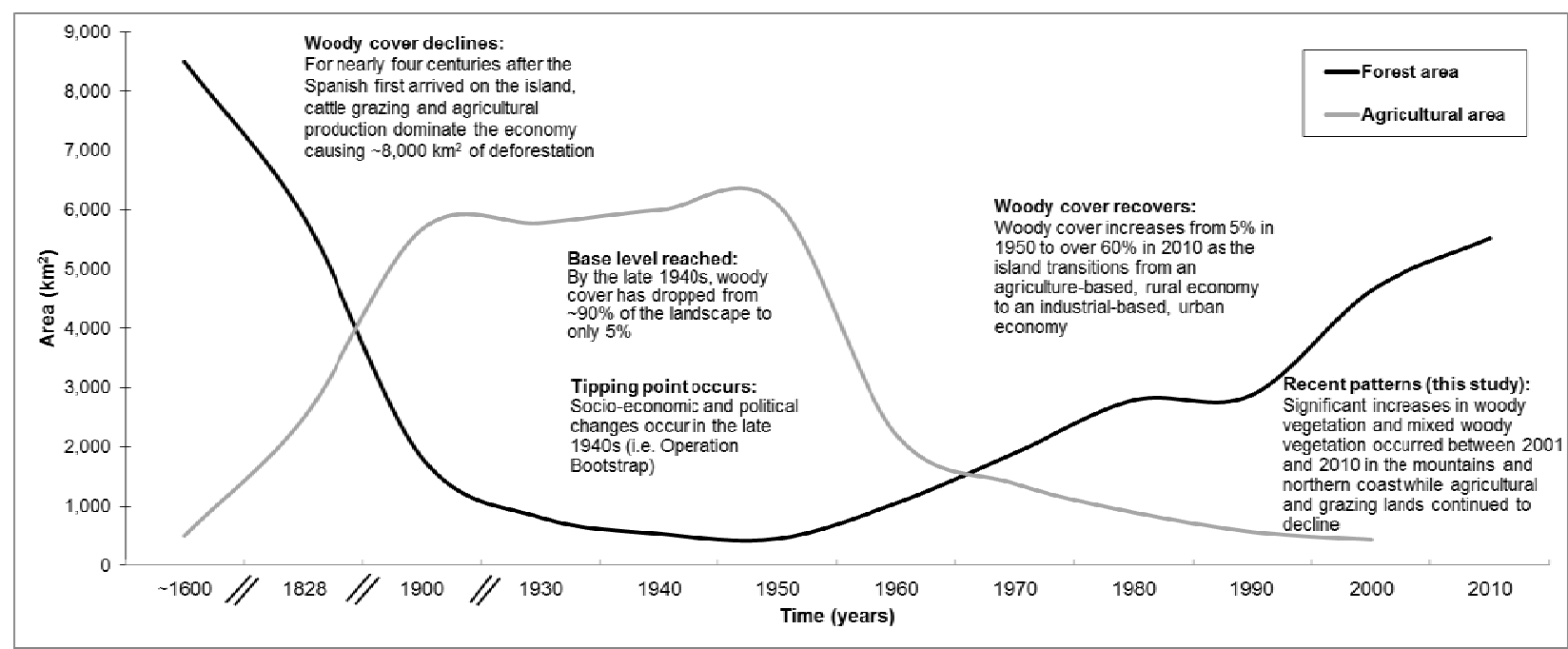

The recovery of woody vegetation in Puerto Rico has mainly consisted of early successional species that are successful exotic invaders or widespread pioneers in tropical regions. The establishment of a woody cover composed by exotic tree species have facilitated the regeneration of native tree species, and have served as habitat for native organisms. These 'new forests' of Puerto Rico provide numerous 
ecosystem services (e.g., renewal of soil fertility, water purification), but are characterized by fewer endemic species and fewer large trees than old-growth native forests.

Our study shows that from 2001 to 2010 , the general trend of woody recovery has been maintained; a trend also documented by FAO [55]. Woody vegetation regrowth continues to occur in municipalities in the mountainous interior [17], but now also extents along the northern Atlantic coast (Figure 1(a)). The regrowth of woody vegetation and increases in the mixed-woody/plantations class observed in municipalities along the northern coast was associated with a decrease in the agriculture/herbaceous class. The increases in the woody vegetation and mixed-woody/plantations classes suggest that abandoned areas of agriculture/herbaceous vegetation are undergoing a gradual secondary succession through natural processes. In the mountainous interior (e.g. municipalities of Cayey and Gurabo), increases in woody vegetation were associated with decreases in mixed-woody class, suggesting the recovery of woody vegetation. Part of the increase in the mixed-woody/plantations class could be attributed to an increase in tree plantations, but data from FAOSTATS [33] indicates an overall decrease in plantations in Puerto Rico, with coffee as the crop that lost the most area in the last decade.

Our study also detected decreases in woody vegetation in municipalities in the western region of Puerto Rico. This region is undergoing urban expansion, particularly around the main city of Mayagüez. In addition, loss of woody vegetation was associated with an increase in the mixed-woody/plantations class in the western municipalities of Añasco and Las Marías, indicating the fragmentation of woody vegetation stands. The loss of agricultural lands was the dominant land change in Puerto Rico $\left(-119 \mathrm{~km}^{2}\right)$ encompassing municipalities all around the island (Figure 1(b)).

From 2000 to 2010, the total population of Puerto Rico declined by $\sim 80,000$ or $2 \%$ [56], and the urban population continues to exceed rural population growth. Although urbanization contributed to woody regrowth in the past [15], recent patterns of urban expansion are the major driver of deforestation and forest fragmentation in the island [57]. In the early 2000s, developed land in Puerto Rico covered approximately $950 \mathrm{~km}^{2}$, equivalent to $\sim 11 \%$ of the island; $60 \%$ of this urban cover was located along the coastal plains [58]. In a scenario of further economic stagnation and sustained population decline, woody cover will likely continue to expand as areas that are presently classified as mixed woody transition into the woody vegetation class.

\subsection{Land Change in Haiti}

Haiti was the only country of the six islands in the Greater Antilles that experienced net woody vegetation loss $\left(-21 \mathrm{~km}^{2}\right)$, but we also detected a large increase in the mixed-woody/plantations class $\left(+368 \mathrm{~km}^{2}\right)$ (Table 3$)$. Two factors could be contributing to the observed increase of the mixed-woody/ plantations class. First, according to FAOSTATS [33], between 2001 and 2010 the area in coffee and cocoa plantations increased by $404 \mathrm{~km}^{2}$ and $139 \mathrm{~km}^{2}$ respectively. Second, the increase in mixed-woody cover could represent an early sign of vegetation regrowth stimulated by two years (i.e., 2007, 2010) of unusually high precipitation [59]. Some of the areas undergoing an increase in the mixed-woody class are within the dry forest ecoregion in the northeast, and slight increases in precipitation can stimulate the growth of many xeric species (e.g., cactus, Leucaena spp., Bursera simaruba, Prosopis glandulosa) [60]. In this region, we also detected an increase in woody vegetation suggesting an extensive area of regrowth. These results coincide with recent studies of land change in 
other regions in Latin America, which have found strong correlation between higher precipitation and increases in woody cover in arid zones [27,61].

We also detected a large decrease in the agriculture/herbaceous vegetation class $\left(-301 \mathrm{~km}^{2}\right.$ from 2001 to 2010); contradicting FAO data, which estimates an increase in crop area harvested $\left(+270 \mathrm{~km}^{2}\right)$. This discrepancy may be due to the conversion of herbaceous vegetation (e.g., pastures) to agriculture, a land-use transition that would not be detected in our data. A limitation of our methodology is the relatively low accuracy values for individual classes that are spectrally similar (e.g., agriculture and herbaceous). Yet, our methodology has the advantage of using 10 years of data and only including changes that had a significant trend over the 10 years of analysis. In addition, the discrepancy between our findings and FAO's could be partially attributed to inaccuracies in the agricultural statistics provided to FAO, given the weak institutional conditions of government organizations in Haiti.

Most studies of deforestation in Haiti identify the growing population, agriculture, and the demand for fuelwood as major driving factors of deforestation [62]. Historically, Haiti underwent rapid woody loss as agricultural lands (e.g., sugarcane, cotton, and coffee) expanded during the periods of occupation by the French (1697-1791) and the Americans (1915-1934). As a result, woody cover decreased from $\sim 80 \%$ in the 1500 s to $\sim 21 \%$ in the early 1940 s [63]. In the following decades, deforestation continued mainly because of a rapid increase in population, and the increased pressure to cut woody vegetation for fuelwood and subsistence agriculture. By 1954, total woody cover was estimated at $8 \%-9 \%$, and by 1978 , it dropped to an estimated $6.7 \%$. Deforestation accelerated during the embargo imposed by the United Nations from 1991 to 1994 when kerosene and petroleum imports were affected by the economic blockade, resulting in further clearing of remaining woody stands for fuelwood (mostly for cooking) [64]. As a result, total woody cover was reduced to approximately $1 \%$ [65] to $3 \%$ [66], by the early 2000 s, but we estimated the woody class ( $>80 \%$ cover) to be $\sim 7 \%$ in 2001 (Table 4).

Remaining woody cover in Haiti could be threatened [67] given rapid population growth (from 6.1 million in 1989 to 10 million in 2010) [22], agricultural expansion, and increased pressure on forest resources after the 7.0 magnitude earthquake that struck on Jan. 2010. Dependence of fuelwood continues to be a major contributor to deforestation as approximately $94 \%$ of the population uses wood or charcoal for cooking [68]. Further deforestation will likely continue to amplify the impact of earthquakes, hurricanes, erosion, landslides, and other natural phenomena on Haiti's population. However, our remotely-sensed data also detected a significant increase of mixed-woody/plantations cover, suggesting an increase in vegetation cover between 2001 and 2010. These findings highlight the importance of analyzing reforestation and deforestation processes simultaneously, and in the case of Haiti emphasize the need for a more recent and finer-scale study of woody regrowth.

\subsection{Land Change in the Dominican Republic}

Between 2001 and 2010, the Dominican Republic experienced a relatively stable woody vegetation trend, in which woody gain slightly exceeded woody loss $\left(+4 \mathrm{~km}^{2}\right)$, and there was an increase in the mixed-woody/plantations class $\left(+707 \mathrm{~km}^{2}\right)$. The large increase in the mixed-woody/plantations class may be the combination of two processes: (1) plantations such as plantains, bananas and mango have nearly doubled their production during the decade [33]; and (2) mixed-woody cover may also result 
from gradually abandonment of marginal grazing lands accompanied by early stages of woody vegetation succession [69]. The regeneration of woody vegetation after the abandonment of grazing lands could be a continuation of the trend observed in previous years. For example, during the 1980s and 1990s, deforestation was significant in the lowland karst region of Los Haitises [70], but many of these areas have been abandoned and are in the process of secondary succession [71]. Between 1984 and 2002, the 13 municipalities in the north-western region had a net increase in woody cover, mainly due to pasture abandonment, accompanied by the country's rapid economic growth, and rural-urban migration [18]. During the past decade, urban population growth continued to exceed rural population growth, likely favouring the abandonment of marginal grazing lands.

Our analysis detected woody vegetation loss in the north-eastern coastal municipalities of María Trinidad and Samaná. Decreases in woody cover in these municipalities can be attributed to the expansion of tourism and urban settlements along the coast [72]. These municipalities also experienced a significant increase in agricultural lands possibly to supply the demand of urban population and tourism. In contrast, we detected significant losses in the agriculture/herbaceous class in three municipalities (Pedernales, San Pedro de Macorís, San Juan) in the south and central region of the island, possibly related to the general trend of decrease in crop areas between 2001 and 2009 as documented by FAO (Table 5), and an overall decline of grazing lands in the mountainous interior (Coordillera Septentrional) [18].

Exotic species has played an important role in the regeneration of woody cover in the Dominican Republic. Woody cover composition after the abandonment of pasturelands has been dominated by exotic tree species comprising a large proportion of the woody basal area $(\sim 20 \%)$, and constituting the main species in the understory of secondary forests.

\subsection{Land Change in Jamaica}

No municipality in Jamaica had a significant trend in woody vegetation between 2001 and 2010 . This tendency of negligible woody vegetation change was also observed in earlier decades. Between 1954 and 1985, woody cover was $\sim 29 \%$ in both years, and between 1989 and 1998 there was only a loss of $30 \mathrm{~km}^{2}$ of woody cover [73]. This loss of woody cover in the late nineties was associated with the expansion of bauxite mining over forests and agricultural lands [74]. At the same time, reforestation occurred in various regions of Jamaica given natural regeneration after the abandonment of coffee and food crops (e.g., yam, onions) [75,76].

Agricultural production has declined in Jamaica since the 1990s due to combined impact of extreme weather events and national financial problems [77]. For instance, in 1997 the island experienced a 17-month drought that caused US $\$ 4.7 \mathrm{~m}$ in damages to the agriculture sector [78]. During 2002-2008, Jamaica had the greatest damage to the agriculture sector caused by the passage of several consecutives hurricanes and storms (Hurricanes Charley and Ivan in 2004, Tropical Storm Wilma, and Hurricanes Dennis and Emily in 2005, and Hurricane Dean and Tropical Storm Noel in 2007), two events of drought (2007 and 2008), and associated bush fires. Consequently, total active farmland in Jamaica decreased by 25.8\% ( 700 $\left.\mathrm{km}^{2}\right)$ between 1996 and 2007 [79]. Our results tend to support this trend, given that we found a slight decrease of the agriculture/herbaceous class. The loss of agricultural/herbaceous land was concentrated around the capital city of Kingston, and can be 
attributed to climatic events, but also to urban expansion. In addition, our analysis of land cover change showed a significant increase in the mixed-woody/plantations class in the St. Catherine municipality. The increase in mixed-woody/plantations class could be partially attributed to the increases in woody vegetation on abandoned farmland; a pattern recently documented in several case studies in Jamaica $[73,74]$.

\section{Conclusions}

Global factors interacting with local socioeconomic conditions have shaped land change dynamics in the Greater Antilles Region. Between 2001 and 2010, land change in the Greater Antilles was dominated by woody vegetation regrowth and agricultural abandonment. The Greater Antilles underwent a net woody vegetation gain of $801 \mathrm{~km}^{2}$ and mixed-woody/plantations increase of $1,482 \mathrm{~km}^{2}$, while agriculture/herbaceous vegetation declined by $1,498 \mathrm{~km}^{2}$.

Given their socioeconomic particularities, Cuba and Haiti represent the most dynamic and unpredictable situations. Nearly all of the gain in woody vegetation can be attributed to the decline of sugarcane cultivation and the expansion of an invasive shrub on abandoned fields in Cuba. Haiti continued to lose woody vegetation, mainly for fuelwood consumption and agricultural expansion [33]; however, early succession of vegetation was detected in several regions of the island. Given the uncertain future relationships with global market economy and socioeconomic pathways that will define demographic and economic conditions, both Cuba and Haiti emerge as important regions for focusing land use monitoring given that these countries will define the balance of land cover types for the whole region.

Woody vegetation also increased slightly in Puerto Rico and Dominican Republic following a more typical Latin American pattern of woody recovery in which land abandonment occurs on marginal agricultural lands, associated with socioeconomic development and population urbanization [5]. Jamaica could be following a similar transition as suggested by a pattern of early woody succession on abandoned agricultural lands. These three countries appear to be reaching relatively stable land configurations with urban development concentrated in the lowlands and regenerating forests in the mountains.

While the regional gains in woody cover and declines in cash crop production can be viewed as beneficial to the environment, the loss of local agriculture poses great challenges for the Greater Antilles region. Between 1990 and 2009 the region's population increased by 27\% [22], while agricultural area declined by $33 \%$ and production by $70 \%$ [33]. The decline in food production, suggests that the countries of the Greater Antilles will become more dependent on food imports, thereby becoming more vulnerable to global fluctuations in food prices, as well as causing indirect impacts on the environment in areas of the world where the imported food is produced [80].

Overall, the more stable socioeconomic systems of Puerto Rico, Jamaica, and the Dominican Republic are associated with a relatively stable land configuration. In contrast, land change dynamics in Cuba and Haiti will depend on how these countries become integrated into the global economy. These dynamics will greatly influence the balance between opportunities and threats for the Greater Antilles environment in the coming decades. 


\section{Acknowledgments}

This research was funded by a grant from the Dynamics of Couple Natural and Human systems program of NSF (\#0709598 and \#0709645). NSF IGERT (\#0801577), and NSF GRFP provided financial support to N. A-B. We thank Luis Villanueva, José Ortíz, Isabel Parés, Martha Bonilla, Serge Aucoin, Johnny Lugo, and three anonymous reviewers for their helpful comments. We also thank George Riner at Sonoma State University for his assistance with satellite image processing.

\section{References}

1. Foley, J.A.; DeFries, R.S.; Asner, G.P.; Barford, C.; Bonan, G.; Carpenter, S.R.; Chapin, F.S.; Coe, M.T.; Daily, G.C.; Gibbs, H.K.; et al. Global consequences of land use. Science 2005, 309, 570-574.

2. Gibbs, H.K.; Ruesch, A.S.S.; Achard, F.; Clayton, M.K.K.; Holmgren, P.; Ramankutty, N.; Foley, J.A. Tropical forests were the primary sources of new agricultural land in the $1980 \mathrm{~s}$ and 1990s. Proc. Natl. Acad. Sci. USA 2010, 107, 1-6.

3. Lambin, E.F.; Geist, H.J.; Lepers, E. Dynamics of land-use and land-cover change in tropical regions. Ann. Rev. Environ. Resour. 2003, 28, 205-241.

4. Morton, D.C.; DeFries, R.S.; Shimabukuro, Y.E.; Anderson, L.O.; Arai, E.; del Bon Espirito-Santo, F.; Freitas, R.M.; Morisette, J.J.T. Cropland expansion changes deforestation dynamics in the southern Brazilian Amazon. Proc. Natl. Acad. Sci. USA 2006, 103, 14637-14641.

5. Lambin, E.F.; Turner, B.L., II; Geist, H.J.; Agbola, S.B.; Angelsen, A.; Folke, C.; Bruce, J.W.; Coomes, O.T.; Dirzo, R.; George, P.S.S.; et al. The causes of land-use and land-cover change: Moving beyond the myths. Glob. Environ. Change 2001, 11, 261-269.

6. Grau, H.R.; Aide, T.M. Globalization and land use transitions in Latin America. Ecol. Soc. 2008, 13,16 .

7. O’Brien, K.L.; Leichenko, R.M. Double exposure: Assessing the impacts of climate change within the context of economic globalization. Glob. Environ. Change 2000, 10, 221-232.

8. Gamble, D.W.; Campbell, D.; Allen, T.L.; Barker, D.; Mcgregor, D.; Popke, J.; Curtis, S. Climate change, drought, and Jamaican agriculture: Local knowledge and the climate record. Ann. Assoc. Am. Geogr. 2010, 100, 880-893.

9. Wilkie, M.L.; Eckelmann, M.; Laverdiere, M.; Mathias, A. Forests and forestry in small island developing states. Int. For. Rev. 2002, 4, 257-267.

10. Food and Agriculture Organization-United Nations (FAO-UN). Global Forest Resources Assessment 2000. Main Forest Report. Forestry Paper 40; FAO: Rome, Italy, 2001.

11. Economic Commission for Latin America and the Caribbean-United Nations (UNECLAC). Chapter 11. The Effects of Globalization on CARICOM Caribbean Economies. In Globalization and Development; Comisión Económica para América Latina y el Caribe (CEPAL): Santiago, Chile, 2002; pp. 331-354.

12. Pelling, M.; Uitto, J.I. Small island developing states: Natural disaster vulnerability and global change. Glob. Environ. Change B Environ Hazards 2002, 3, 49-62. 
13. Myers, N.; Mittermeier, R.A.; Mittermeier, C.G.; da Fonseca, G.A.; Kent, J. Biodiversity hotspots for conservation priorities. Nature 2000, 403, 853-858.

14. Brothers, T.S. Deforestation in the Dominican Republic: A village-level view. Environ. Conserv. 1997, 24, 213-223.

15. Grau, H.R.; Aide, T.M.; Zimmerman, J.K.; Thomlinson, J.R.; Helmer, E.H.; Zou, X. The ecological consequences of socioeconomic and land-use changes in postagriculture Puerto Rico. BioScience 2003, 53, 1159-1168.

16. Crk, T.; Uriarte, M.; Corsi, F.; Flynn, D. Forest recovery in a tropical landscape: What is the relative importance of biophysical, socioeconomic, and landscape variables? Landsc. Ecol. 2009, 24, 629-642.

17. Yackulic, C.B.; Fagan, M.; Jain, M.; Jina, A.; Lim, Y.; Marlier, M.; Muscarella, R.; Adame, P.; DeFries, R.S.; Uriarte, M. Biophysical and socioeconomic factors associated with forest transitions at multiple spatial and temporal scales. Ecol. Soc. 2011, 16, 15.

18. Grau, H.R.; Pérez Ceballos, M.; Martinuzzi, S.; Encarnación, X.; Aide, T.M. Cambios Socioeconómicos y Regeneración del Bosque en la República Dominicana. In Restauración de Bosques en América Latina; González-Espinosa, M., Rey Benayas, J.M., Ramírez-Marcial, N., Eds.; Mundi-Prensa/Fundación Internacional para la Restauración de Ecosistemas: Mexico, 2008; pp. 211-227.

19. Newman, M.E.; McLaren, K.P.; Wilson, B.S. Use of object-oriented classification and fragmentation analysis (1985-2008) to identify important areas for conservation in Cockpit Country, Jamaica. Environ. Monit. Assess. 2011, 172, 391-406.

20. Versluis, A.; Rogan, J. Mapping land-cover change in a Haitian watershed using a combined spectral mixture analysis and classification tree procedure. Geocarto Int. 2010, 25, 85-103.

21. Wilson, J.S.; Brothers, T.S.; Marcano, E.J. Remote sensing of spatial and temporal vegetation dynamics in Hispaniola: A comparison of Haiti and the Dominican Republic. Geocarto Int. 2001, $16,7-18$.

22. United Nations World Population Prospects: The 2009 Revision Population Database. Available online: http://esa.un.org/wup2009/unup/index.asp?panel=1 (accessed on 20 October 2012).

23. Vagts, K.A. Conifers in Cuba. Conifer Soc. 2004, 20, 36-40.

24. World Bank. World Development Indicators. Available online: http://data.worldbank.org/ data-catalog/world-development-indicators/wdi-2011 (accessed on 13 September 2012).

25. Clark, M.L.; Aide, T.M.; Riner, G. Land change for all municipalities in Latin America and the Caribbean assessed from 250-m MODIS imagery (2001-2010). Remote Sens. Environ. 2012, 126, 84-103.

26. Huete, A.R.; Didan, K.; Miura, T.; Rodriguez, E.P.; Gao, X.; Ferreira, L.G. Overview of the radiometric and biophysical performance of the MODIS vegetation indices. Remote Sens. Environ. 2002, 83, 195-213.

27. Aide, T.M.; Clark, M.L.; Grau, H.R.; López-Carr, D.; Levy, M.a.; Redo, D.; Bonilla-Moheno, M.; Riner, G.; Andrade-Núñez, M.J.; Muñiz, M. Deforestation and reforestation of Latin America and the Caribbean (2001-2010). Biotropica 2012, 45, 262-271.

28. Breiman, L. Random forests. Machine Learn. 2001, 45, 5-32. 
29. Clark, M.L.; Aide, T.M. Virtual interpretation of Earth Web-Interface Tool (VIEW-IT) for collecting land-use/land-cover reference data. Remote Sens. 2011, 3, 601-620.

30. Liaw, A.; Wiener, M. Classification and regression by randomForest. R News 2002, 2, 18-22.

31. The R Development Core Team. R: A Language and Environment for Statistical Computing; $\mathrm{R}$ Foundation for Statistical Computing: Vienna, Austria, 2011.

32. Grainger, A. Difficulties in tracking the long-term global trend in tropical forest area. Proc. Natl. Acad. Sci. USA 2008, 105, 818-823.

33. Food and Agriculture Organization of the United Nations (FAOSTATS). Available online: http://faostat.fao.org/default.aspx (accessed on 13 October 2011).

34. Guerra, Y.; Sánchez, R. Sugar and Society in the Caribbean: An Economic History of Cuban Agriculture (Volume 7, The Caribbean Series); Yale University Press: New Haven, CT, USA/London, UK, 1964.

35. Feuer, C.H. The performance of the Cuban sugar industry, 1981-1985. World Dev. 1987, 15, 67-81.

36. Peters, P. Cutting Losses: Cuba. Downsizes Its Sugar Industry; Lexington Institute: Arlington, VA, USA, 2003; pp. 1-16.

37. Febles-González, J.M.; Tolón-Becerra, A.; Lastra-Bravo, X.; Acosta-Valdés, X. Cuban agricultural policy in the last 25 years. From conventional to organic agriculture. Land Use Policy 2011, 28, $723-735$.

38. Lambert, M. Forest Management in Cuba: An Environmental History of the 20th Century. Honours Thesis, Dalhousie University, Halifax, NS, Canada, 2008.

39. Oficina Nacional de Estadística e Información de Cuba. Anuario Estadístico de Cuba 2010. Available online: http://www.one.cu/aec2010/esp/02_tabla_cuadro.htm (accessed on 22 February 2013).

40. Periódico Radio Santa Cruz. Alistan Central 30 de Noviembre Para Zafra Azucarera; Camagüey, Cuba, 2011.

41. InfoMine Moa. Avaialbe online: http://www.infomine.com/index/properties/MOA.html (accessed on 22 Feburary 2013).

42. Dichrostachys Cinerea; Global Invasive Species Database. Available online: http://www.issg.org/database/species/ecology.asp?si=161 (accessed on 15 October 2012).

43. Ravsburg, F. A Weed that Could Bring Power to Cuba. Available online: http://www.havanatimes.org/?p=25541 (accssed on 22 February 2013).

44. Baumann, M.; Kuemmerle, T.; Elbakidze, M.; Ozdogan, M.; Radeloff, V.C.; Keuler, N.S.; Prishchepov, A.V.; Kruhlov, I.; Hostert, P. Patterns and drivers of post-socialist farmland abandonment in Western Ukraine. Land Use Policy 2011, 28, 552-562.

45. Rudel, T.K.; Coomes, O.T.; Moran, E.F.; Achard, F.; Angelsen, A.; Xu, J.; Lambin, E.F.; Archard, F. Forest transitions: Towards a global understanding of land use change. Glob. Environ. Change 2005, 15, 23-31.

46. Kuemmerle, T.; Olofsson, P.; Chaskovskyy, O.; Baumann, M.; Ostapowicz, K.; Woodcock, C.E.; Houghton, R.A.; Hostert, P.; Keeton, W.S.; Radeloff, V.C. Post-Soviet farmland abandonment, forest recovery, and carbon sequestration in western Ukraine. Glob. Change Biol. 2011, 17, 1335-1349.

47. Lugo, A.E.; Helmer, E.H. Emerging forests on abandoned land: Puerto Rico's new forests. For. Ecol. Manag. 2004, 190, 145-161. 
48. Aide, T.M.; Zimmerman, J.K.; Pascarella, J.B.; Rivera, L.W.; Marcano-Vega, H. Forest regeneration in a chronosequence of tropical abandoned pastures: Implications for restoration ecology. Restor. Ecol. 2000, 8, 328-338.

49. Birdsey, R.A.; Weaver, P.L. Forest Area Trends in Puerto Rico; Res. Note SO-331; US Department of Agriculture, Forest Service, Southern Forest Experiment Station: New Orleans, LA, USA, 1987; pp. 1-5.

50. Koop, G.; Tole, L. Measuring differential forest outcomes: A tale of two countries. World Dev. 1997, 25, 2043-2056.

51. Cruz Baez, A.; Boswell, T. Atlas of Puerto Rico; Cuban American National Council: Miami, FL, USA, 1997.

52. Dietz, J.L. Economic History of Puerto Rico; Princeton University Press: Princeton, NJ, USA, 1986.

53. Brandeis, T.J.; Helmer, E.H.; Oswalt, S.N. The Status of Puerto Rico's Forests, 2003; US Department of Agriculture Forest Service, Southern Research Station: Knoxville, TN, USA, 2007; pp. 1-93.

54. Birdsey, R.A.; Weaver, P.L. Forest Area Trends in Puerto Rico; Research Note SO-331; US Department of Agriculture, Forest Service, Southern Forest Experiment Station: New Orleans, LA, USA, 1987; pp. 1-5.

55. Food and Agriculture Organization of the United Nations (FAO-UM). Global Forest Resources Assessment Main Report: FAO Forestry Paper \#163; Rome, Italy, 2010; pp. 1-378.

56. United States Census Bureau Censtats Databases. Available online: http://censtats.census.gov/ (accessed on 19 September 2012).

57. Parés-Ramos, I.K.; Gould, W.A.; Aide, T.M. Agricultural abandonment, suburban growth, and forest expansion in Puerto Rico between 1991 and 2000. Ecol. Soc. 2008, 13, 1.

58. Martinuzzi, S.; Gould, W.A.; Ramosgonzalez, O.; Ramos González, O.M. Land development, land use, and urban sprawl in Puerto Rico integrating remote sensing and population census data. Landsc. Urban Plan. 2007, 79, 288-297.

59. Organization for the Rehabilitation of the Environment Rainfall Data (Haiti). Available online: http://www.oreworld.org/rainfall.htm (accessed on 11 October 2012).

60. Pauleus, O. Personal Communication. University of Puerto Rico, Río Piedras, PR, USA, October 2012.

61. Bonilla-Moheno, M.; Aide, T.M.; Clark, M.L. The influence of socioeconomic, environmental, and demographic factors on municipality-scale land-cover change in Mexico. Reg. Environ. Change 2011, 12, 543-557.

62. Dolisca, F. Population Pressure, Land Tenure, Deforestation, and Farming Systems in Haiti: The Case of Forêt des Pins Reserve. Ph.D. Thesis, Auburn University, Auburn, AL, USA, 2005; pp. 1-213.

63. Béliard, C.A.; Norris, J.M.D. Dégradation de L'environnement Haïtien: (Manifestations, Causes, Conséquenceset Alternatives); Association Nationale des Agro-Professionnels Haitiens: Port-au-Prince, Haiti, 1999.

64. Roc, N. Haiti-Environment: From the «Pearl of the Antilles» to Desolation; Fundación para las Relaciones Internacionales y el Diálogo Exterior (FRIDE): Madrid, Spain, 2008; pp. 1-7.

65. Erikson, D. The Haiti dilemma. Brown J. World Aff. 2004, 10, 285-297. 
66. Dolisca, F.; McDaniel, J.M.; Teeter, L.D.; Jolly, C.M. Land tenure, population pressure, and deforestation in Haiti: The case of forêt des pins reserve. J. For. Econ. 2007, 13, 277-289.

67. Dolisca, F.; McDaniel, J.M.; Teeter, L.D. Farmers' perceptions towards forests: A case study from Haiti. For. Policy Econ. 2007, 9, 704-712.

68. Global Alliance for Clean Cookstoves Haiti. Available online: http://www.cleancookstoves.org/ countries/america/haiti.html (accessed on 5 November 2012).

69. Slocum, M.G.; Aide, T.M.; Zimmerman, J.K.; Navarro, L. Natural regeneration of subtropical montane forest after clearing fern thickets in the Dominican Republic. J. Trop. Ecol. 2004, 20, 483-486.

70. Brothers, T.S. Rapid destruction of a lowland tropical forest, Los Haitises, Dominican Republic. Ambio 1997, 26, 551-552.

71. Rivera, L.W.; Zimmerman, J.K.; Aide, T.M. Forest recovery in abandoned agricultural lands in a karst region of the Dominican Republic. Plant Ecol. 2000, 148, 115-125.

72. Aide, T.M. Personal Communication. University of Puerto Rico, Río Piedras, PR, USA, January 2013.

73. Evelyn, O.B.; Camirand, R. Forest cover and deforestation in Jamaica: An analysis of forest cover estimates over time. Int. For. Rev. 2003, 5, 354-363.

74. Jamaica Ministry of Agriculture. National Forest Management and Conservation Plan; Forestry Department, Ministry of Agriculture: Jamaica, Cuba, 2001; p. 100.

75. Eckelmann, C. Deforestation, Agriculture, and Recovery of Forest Cover in the Caribbean. In Possibilities and Approaches to Idle Lands in the Caribbean: Proceedings of the Thirteenth Meeting of Caribbean Foresters in Jamaica; Weaver, P., Bauer, G.P., Eds.; US Department of Agriculture, Forest Service, International Institute of Tropical Forestry: Río Piedras, Puerto Rico, 2007; pp. 40-49.

76. Timms, B.F.; Hayes, J.; McCracken, M. From deforestation to reforestation: applying the forest transition to the Cockpit Country of Jamaica. Area 2012, 1, 77-87.

77. Campbell, D.; Barker, D.; McGregor, D.F.M. Dealing with drought: Small farmers and environmental hazards in southern St. Elizabeth, Jamaica. Appl. Geogr. 2011, 31, 146-158.

78. Mills, C.; Reporter, F. Climate Changes Hurt Farming. Available online: http://jamaica-gleaner.com/gleaner/20001203/news/news1.html (accessed on Date Month Year).

79. Statistical Institute of Jamaica Agricultural Census. Available online: http://statinja.gov.jm/ (accessed on 27 August 2012).

80. Lambin, E.F.; Meyfroidt, P. Global land use change, economic globalization, and the looming land scarcity. Proc. Natl. Acad. Sci. USA 2011, 108, 3465-3472.

\section{Appendix}

Table S1. Municipalities which underwent significant change $(p \leq 0.05)$ by country, and area $\left(\mathrm{km}^{2}\right)$ of land change for each class.

\begin{tabular}{|c|c|c|c|c|c|}
\hline Country & Municipality & Municipality Area $\left(\mathrm{km}^{2}\right)$ & Woody $\left(\mathrm{km}^{2}\right)$ & Plant/Mixed $\left(\mathrm{km}^{2}\right)$ & $\operatorname{Ag} / \operatorname{Herb}\left(\mathrm{km}^{2}\right)$ \\
\hline Cuba & Alquizar & 228.05 & & -12.83 & \\
\hline Cuba & Bayamo & 864.17 & 100.92 & & \\
\hline
\end{tabular}


Table S1. Cont.

\begin{tabular}{|c|c|c|c|c|c|}
\hline Country & Municipality & $\begin{array}{c}\text { Municipality Area } \\
\left(\mathbf{k m}^{2}\right)\end{array}$ & $\begin{array}{c}\text { Woody } \\
\left(\mathrm{km}^{2}\right)\end{array}$ & $\begin{array}{c}\text { Plant/Mixed } \\
\left(\mathbf{k m}^{2}\right)\end{array}$ & $\begin{array}{c}\mathrm{Ag} / \text { Herb } \\
\left(\mathrm{km}^{2}\right)\end{array}$ \\
\hline Cuba & Cacocum & 665.41 & 12.37 & & \\
\hline Cuba & Caimanera & 560.70 & & 75.42 & \\
\hline Cuba & Cárdenas & 835.19 & 53.21 & & \\
\hline Cuba & Cauto Cristo & 405.10 & 33.43 & & \\
\hline Cuba & Cifuentes & 523.90 & 19.82 & 95.92 & -116.04 \\
\hline Cuba & Colombia & 512.05 & 55.18 & & \\
\hline Cuba & Colón & 505.25 & 10.39 & & \\
\hline Cuba & Diez De Octubre & 15.48 & -0.53 & -0.17 & \\
\hline Cuba & El Salvador & 599.20 & & -43.18 & \\
\hline Cuba & Isla De La Juventud & 2442.75 & & 162.95 & \\
\hline Cuba & Jagüey Grande & 787.99 & 70.29 & & \\
\hline Cuba & Jiguani & 756.91 & 35.96 & & -105.02 \\
\hline Cuba & Jovellanos & 465.77 & 18.78 & & \\
\hline Cuba & La Lisa & 43.75 & -0.12 & & \\
\hline Cuba & La Palma & 701.94 & -97.76 & & \\
\hline Cuba & Limonar & 575.78 & 56.43 & & \\
\hline Cuba & Los Arabos & 777.91 & 177.54 & & -142.64 \\
\hline Cuba & Los Palacios & 792.57 & -58.88 & & \\
\hline Cuba & Manuel Tames & 488.75 & 53.45 & & -65.04 \\
\hline Cuba & Manzanillo & 540.92 & 43.38 & & \\
\hline Cuba & Marianao & 17.21 & -0.24 & & \\
\hline Cuba & Moa & 559.00 & -29.77 & 25.68 & \\
\hline Cuba & Perico & 329.94 & 11.10 & 23.64 & -34.64 \\
\hline Cuba & Quemado De Gines & 313.13 & 21.65 & & \\
\hline Cuba & Ranchuelo & 550.20 & 11.97 & & \\
\hline Cuba & Rodas & 464.80 & 22.06 & & \\
\hline Cuba & Sagua De Tánamo & 776.71 & 89.42 & & \\
\hline Cuba & San Cristóbal & 784.79 & -95.31 & & \\
\hline Cuba & San José De La Lajas & 511.62 & 20.36 & & \\
\hline Cuba & San Luis & 628.49 & 45.57 & & \\
\hline Cuba & Santo Domingo & 820.97 & 118.69 & & -214.24 \\
\hline Cuba & Venezuela & 518.42 & & & -75.13 \\
\hline Sub total & & & 799.34 & 327.42 & -752.76 \\
\hline $\begin{array}{l}\text { Dominican } \\
\text { Republic }\end{array}$ & Bahoruco & 1312.70 & 171.82 & & \\
\hline $\begin{array}{l}\text { Dominican } \\
\text { Republic }\end{array}$ & Distrito Nacional & 84.61 & & & -2.58 \\
\hline $\begin{array}{l}\text { Dominican } \\
\text { Republic }\end{array}$ & Hato Mayor & 1322.42 & & 135.07 & \\
\hline $\begin{array}{l}\text { Dominican } \\
\text { Republic }\end{array}$ & Independencia & 1994.58 & & 142.39 & \\
\hline $\begin{array}{l}\text { Dominican } \\
\text { Republic }\end{array}$ & $\begin{array}{l}\text { María Trinidad } \\
\text { Sánchez }\end{array}$ & 1336.52 & -88.16 & & 109.59 \\
\hline
\end{tabular}


Table S1. Cont.

\begin{tabular}{|c|c|c|c|c|c|}
\hline Country & Municipality & $\begin{array}{c}\text { Municipality Area } \\
\left(\mathbf{k m}^{2}\right)\end{array}$ & $\begin{array}{c}\text { Woody } \\
\left(\mathrm{km}^{2}\right)\end{array}$ & $\begin{array}{c}\text { Plant/Mixed } \\
\left(\mathbf{k m}^{2}\right) \\
\end{array}$ & $\begin{array}{c}\text { Ag/Herb } \\
\left(\mathbf{k m}^{2}\right)\end{array}$ \\
\hline $\begin{array}{c}\text { Dominican } \\
\text { Republic }\end{array}$ & Pedernales & 2045.24 & & & -160.89 \\
\hline $\begin{array}{c}\text { Dominican } \\
\text { Republic }\end{array}$ & Samaná & 906.51 & -129.64 & & 34.50 \\
\hline $\begin{array}{c}\text { Dominican } \\
\text { Republic }\end{array}$ & San Cristóbal & 1213.42 & & 98.98 & \\
\hline $\begin{array}{c}\text { Dominican } \\
\text { Republic }\end{array}$ & San Juan & 3343.11 & & & -158.18 \\
\hline $\begin{array}{c}\text { Dominican } \\
\text { Republic }\end{array}$ & $\begin{array}{l}\text { San Pedro de } \\
\text { Macorís }\end{array}$ & 1219.20 & 49.68 & & -123.69 \\
\hline $\begin{array}{c}\text { Dominican } \\
\text { Republic }\end{array}$ & Santiago & 2774.37 & & 330.56 & \\
\hline Sub total & & & 3.70 & 707.00 & -301.25 \\
\hline Haiti & Aguahedionde & 170.99 & 1.09 & & \\
\hline Haiti & Aux Cadets & 46.25 & & 7.15 & \\
\hline Haiti & Baconnois & 34.39 & & -4.97 & \\
\hline Haiti & Bais D'orange & 68.04 & & & -8.76 \\
\hline Haiti & Balan & 114.55 & & 0.37 & \\
\hline Haiti & Bas Coursin & 48.01 & & -0.54 & 0.62 \\
\hline Haiti & Bassin Caiman & 19.18 & & -1.79 & \\
\hline Haiti & Bayaha & 62.82 & 3.02 & & \\
\hline Haiti & Beaumont & 95.01 & & 5.32 & \\
\hline Haiti & Belle Fontaine* & 154.46 & & 16.50 & \\
\hline Haiti & Bellevue (Ouest) & 12.78 & & & -3.69 \\
\hline Haiti & Bellevue (Sud) & 40.08 & & 14.17 & -14.23 \\
\hline Haiti & $\begin{array}{l}\text { Bellevue La } \\
\text { Montagne }\end{array}$ & 33.88 & & 8.04 & \\
\hline Haiti & Bino (Premiere Plain & 44.15 & -0.67 & & \\
\hline Haiti & Bois Blanc & 12.78 & & 4.89 & -4.84 \\
\hline Haiti & Bois De Lance & 39.80 & & 9.31 & -11.25 \\
\hline Haiti & Borneau & 20.55 & -5.65 & 4.54 & \\
\hline Haiti & Boucan Guillaume & 127.86 & & 67.49 & -62.37 \\
\hline Haiti & Boudon & 39.64 & & & 0.22 \\
\hline Haiti & Bourdet & 53.00 & & & 6.16 \\
\hline Haiti & Brodequin & 40.61 & 2.07 & & \\
\hline Haiti & Callumette & 28.35 & & & -6.93 \\
\hline Haiti & Champin & 30.87 & 1.48 & & \\
\hline Haiti & Colline Des Chaines & 80.13 & & 17.27 & \\
\hline Haiti & Corail Thor & 5.63 & & 1.01 & \\
\hline Haiti & Dejean & 28.61 & -7.27 & 6.51 & \\
\hline Haiti & Des Delices & 96.07 & 0.08 & & \\
\hline Haiti & Desormeau & 17.09 & & & 0.25 \\
\hline Haiti & Duchity & 66.48 & -7.68 & 7.77 & \\
\hline Haiti & Dumas & 84.88 & 2.63 & & \\
\hline
\end{tabular}


Table S1. Cont.

\begin{tabular}{|c|c|c|c|c|c|}
\hline Country & Municipality & Municipality Area $\left(\mathrm{km}^{2}\right)$ & Woody $\left(\mathrm{km}^{2}\right)$ & Plant/Mixed $\left(\mathrm{km}^{2}\right)$ & Ag/Herb $\left(\mathrm{km}^{2}\right)$ \\
\hline Haiti & Dumont & 14.14 & & 3.76 & -4.04 \\
\hline Haiti & Flamant & 137.00 & & & -21.66 \\
\hline Haiti & Fond Parisien & 178.43 & & 9.98 & \\
\hline Haiti & Fond Tortue & 32.84 & 6.27 & & \\
\hline Haiti & Fonds Blanc & 119.06 & 5.68 & & \\
\hline Haiti & Fonds Des Blancs (Sud) & 48.84 & & 18.81 & -19.31 \\
\hline Haiti & Fonds-Verrettes & 288.81 & -24.99 & & \\
\hline Haiti & Foulon & 15.05 & & 6.53 & -7.18 \\
\hline Haiti & Frangipane & 124.58 & & & -44.88 \\
\hline Haiti & Gerard & 45.63 & & & -5.32 \\
\hline Haiti & Grand Bassin & 51.36 & 3.51 & & \\
\hline Haiti & Grand Vide & 69.19 & 0.06 & & \\
\hline Haiti & Grande Plaine & 43.50 & & 7.69 & 15.87 \\
\hline Haiti & Gros Marin & 36.80 & & 4.16 & \\
\hline Haiti & Hatty & 67.76 & & -5.26 & \\
\hline Haiti & Ile A Vache & 45.94 & & 6.37 & -7.44 \\
\hline Haiti & La Hoye & 109.72 & & & -13.93 \\
\hline Haiti & La Mielle & 87.84 & 2.35 & & \\
\hline Haiti & La Trouble & 15.71 & & -2.77 & \\
\hline Haiti & La Ville & 15.47 & & -1.47 & \\
\hline Haiti & L'assive/Chaumeau & 48.86 & & & 0.23 \\
\hline Haiti & Laurent & 24.57 & & -1.41 & \\
\hline Haiti & Les Gommiers & 39.83 & & & 1.55 \\
\hline Haiti & Macean & 84.63 & & 15.71 & \\
\hline Haiti & Mapou & 66.62 & 4.86 & 20.03 & -24.51 \\
\hline Haiti & Mare Roseaux & 78.83 & & 6.68 & \\
\hline Haiti & Martineau & 56.27 & 2.51 & & \\
\hline Haiti & Mayance & 24.90 & -9.05 & 9.10 & \\
\hline Haiti & Montagne Noire (Nord) & 13.09 & & 1.37 & \\
\hline Haiti & Montagne Noire (Ouest) & 32.43 & 2.58 & & \\
\hline Haiti & Morne Chandelle & 34.95 & 0.54 & & \\
\hline Haiti & Mouline & 59.98 & & & -3.58 \\
\hline Haiti & Palma & 61.94 & & 17.48 & -18.34 \\
\hline Haiti & Pays Pourri & 94.53 & & 15.68 & \\
\hline Haiti & Petit Bois* & 48.10 & & 0.31 & 9.64 \\
\hline Haiti & Petit Fond & 68.91 & 2.56 & & \\
\hline Haiti & Petite Riviere (Ouest) & 40.91 & & -5.35 & 5.30 \\
\hline Haiti & Petite Source & 67.63 & & & -19.31 \\
\hline Haiti & Pichon & 54.12 & & 21.71 & -21.94 \\
\hline Haiti & Pot De Chambre & 70.04 & & 25.71 & -25.55 \\
\hline Haiti & Procy & 17.53 & 0.16 & & \\
\hline Haiti & Randel & 51.90 & & 2.55 & \\
\hline Haiti & Riviere Blanche & 36.79 & & -4.24 & 4.69 \\
\hline Haiti & Riviere De Barre & 21.09 & -7.23 & 7.08 & \\
\hline Haiti & Riviere Mancelle & 40.20 & & & 7.30 \\
\hline
\end{tabular}


Table S1. Cont.

\begin{tabular}{|c|c|c|c|c|c|}
\hline Country & Municipality & Municipality Area $\left(\mathbf{k m}^{2}\right)$ & Woody $\left(\mathrm{km}^{2}\right)$ & Plant/Mixed $\left(\mathrm{km}^{2}\right)$ & $\operatorname{Ag} / \operatorname{Herb}\left(\mathrm{km}^{2}\right)$ \\
\hline Haiti & Sarazin (Nord Est) & 10.82 & & & -4.07 \\
\hline Haiti & Savane Au Lait & 34.23 & 2.27 & & \\
\hline Haiti & Soucailles & 45.32 & & 6.23 & \\
\hline Haiti & Taifer & 10.34 & & 1.79 & \\
\hline Haiti & Tapion & 25.02 & & 3.73 & -3.40 \\
\hline Haiti & Terre Nette & 40.63 & & & -0.93 \\
\hline Haiti & Tete A Bouf & 44.55 & & 11.25 & -11.32 \\
\hline Haiti & Verone & 23.30 & -2.21 & 1.97 & \\
\hline Sub total & & & -21.04 & 368.18 & -316.94 \\
\hline Jamaica & Kingston & 112.88 & & & -8.14 \\
\hline Jamaica & St. Catherine & 1180.13 & & 60.49 & \\
\hline Sub total & & & & 60.49 & -8.14 \\
\hline Puerto Rico & Añasco & 102.95 & -17.35 & & \\
\hline Puerto Rico & Barceloneta & 48.62 & 2.00 & 7.46 & -9.46 \\
\hline Puerto Rico & Caguas & 153.99 & 11.14 & & -6.85 \\
\hline Puerto Rico & Carolina & 124.27 & & & -5.62 \\
\hline Puerto Rico & Cataño & 15.65 & 0.43 & -0.57 & \\
\hline Puerto Rico & Cayey & 134.94 & 18.39 & -16.44 & \\
\hline Puerto Rico & Coamo & 203.27 & 28.48 & & \\
\hline Puerto Rico & Fajardo & 69.51 & & & -3.59 \\
\hline Puerto Rico & Gurabo & 73.66 & 7.70 & -9.67 & \\
\hline Puerto Rico & Juana Díaz & 157.05 & & & -23.13 \\
\hline Puerto Rico & Las Marías & 121.49 & -31.33 & 31.51 & \\
\hline Puerto Rico & Loíza & 52.97 & & -4.53 & \\
\hline Puerto Rico & Manatí & 119.18 & 10.42 & & -11.94 \\
\hline Puerto Rico & Maricao & 95.36 & & & -0.65 \\
\hline Puerto Rico & Mayagüez & 144.87 & -19.69 & 18.39 & \\
\hline Puerto Rico & Orocovis & 165.55 & & & -8.39 \\
\hline Puerto Rico & Ponce & 293.56 & & & -11.19 \\
\hline Puerto Rico & Sabana Grande & 93.40 & & & -12.46 \\
\hline Puerto Rico & Santa Isabel & 86.81 & 1.09 & & \\
\hline Puerto Rico & Toa Alta & 71.70 & 8.17 & & -6.68 \\
\hline Puerto Rico & Vega Alta & 72.83 & & & -6.67 \\
\hline Puerto Rico & Vega Baja & 133.12 & & & -12.53 \\
\hline Sub total & & & 19.47 & 26.14 & -119.15 \\
\hline Total & & & 801.47 & 1489.24 & -1498.23 \\
\hline
\end{tabular}

* Includes two adjacent administrative municipalities that had the same name in the database.

We added their total areas and land-change area values.

(C) 2013 by the authors; licensee MDPI, Basel, Switzerland. This article is an open access article distributed under the terms and conditions of the Creative Commons Attribution license (http://creativecommons.org/licenses/by/3.0/). 